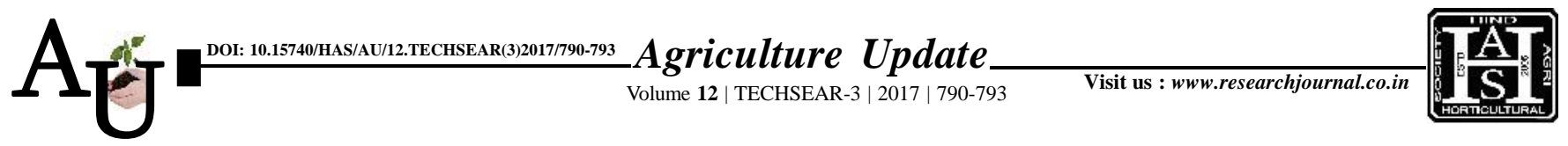

口 e ISSN-0976-6847

\title{
Research Article: Land configuration as a tool for higher yields in rainfed cotton (Gossypium hirsutum L.)
}

\author{
G. VEERANNA, P. RAghU RAMI REDDY, CH. RAMULU AND A. \\ SUDARSHANAM
}

Article Chronicle :

Received :

13.07.2017;

Accepted :

28.07.2017

\section{KeY Words:}

Cotton, Growth, Yield, Nutrient uptake, Crop, Ridges
SUMMARY : A field experiment was conducted at Warangal, Telangana State during Kharif 2014 and 2015 to study the effect of land configuration on growth, yield and, moisture content in the soil and nutrient uptake of rainfed cotton cultivation. The experiment was laid out in Randomized Block Design with treatments land configuration of consists of five methods of cotton sowings viz., ridge and furrow (RF), broad bed furrow (BBF), dust mulching with blade harrow (with appearing hair line soil cracks), deep furrow opening near to crop row at $30 \mathrm{DAS}$ and flat bed (farmers practices). The ridge and furrow method of sowing was found superior as was evident from significant increase in growth and yield attributes, seed cotton yield (1208 kg/ha) and stalk yield (2700 kg/ha), moisture use efficiency (3.6 kg/ $\mathrm{ha} / \mathrm{mm})$ NPK up take $(168,52$ and $240 \mathrm{~kg} / \mathrm{ha})$ and harvesting index $44.5 \%$ and decrease available NPK in the soil after harvest. The land configuration of ridges and furrow was found most effective and feasible for soil moisture conservation and producing the highest cotton yield on sandy loam soil under assured rainfall condition.

How to cite this article : Veeranna, G., Reddy, P. Raghu Rami, Ch. Ramulu and Sudarshanam, A. (2017). Land configuration as a tool for higher yields in rainfed cotton (Gossypium hirsutum L.). Agric. Update, 12(TECHSEAR3) : 790-793; DOI: 10.15740/HAS/AU/12.TECHSEAR(3)2017/790-793.
Author for correspondence :

\section{G. VEERANNA}

Regional Agricultural Research station (PJTSAU), WARANGAL

(TELANGANA) INDIA

Email : veeruag76@ gmail.com

See end of the article for authors' affiliations 